\title{
Hebrews 3:7-4:11 and the Function of Mental Time-Space Landscapes
}

\author{
J. Cornelis de Vos
}

\section{Introduction}

The Epistle to the Hebrews is full of imagery of movements in space and time. "The wandering people of God" (Ernst Käsemann) are on their way to the transcendental realm, to the eschatological city (Heb 13:14). This forces us to take the dimensions of time and space seriously and to analyze the mental time-space landscapes evoked by the text. Such imaginative landscapes can, just like written texts, be seen as meta-texts with their own semantics: the meaning of the points in time and space; their syntax: the meaning of the connections between those points; and their pragmatics: the impact on the mind and behavior of the addressees.

It is important to know, in the analysis of such "landscapes," that topological semes are not value-free. ${ }^{1}$ This goes without saying in a volume about constructions of space. Nevertheless, a few words on this topic can be justified. In general above, before, right, center, and proximity are considered to be good. We call, for example, our forefathers those who are before us, although they are behind us; thus, we hold them in high esteem. On the contrary, bottom, left, behind, and so on are usually deemed bad; cf. "outsider."

The time aspect, however, is also of great importance. In the example mentioned above, the forefathers can be seen both under the aspect of space and of time. The mental spaces evoked by texts can also be memory spaces or future, prospective spaces. The fascinating aspect is that the person in whose mind those spaces emerge can merge those timely different landscapes into a mental timespace landscape with four dimensions: height, length, width, and time. Within these four dimensions there is always a "here and now." But this "here and now" is pregnant with meaning by virtue of its four-dimensionality and thus comprises a powerful aid for the positioning and orientation of an individual or a group. ${ }^{2}$ With regard to the orientation, an even more important consideration is the sacred space, which is always in the center. Sacred space and, equally, holy time create a cosmic order and a feeling of social security. It enables individuals and groups to locate themselves within the cosmos. ${ }^{3}$

By an exemplary exegesis of Heb 3:7-4:11, I would like to demonstrate the

\footnotetext{
${ }^{1}$ See, among others, Gehlen 1995 and 1998. |

${ }^{2}$ See Baudy 1998; Pezzoli-Olgiati 2003.

${ }^{3}$ Bäumer 2003, here 690.
} 
depth of the "here and now" of the pericope by placing it on a time and space axis and relating it to "the sacred." Interestingly, time and space before the "here and now" as well as time and space after the "here and now" mingle with or, better, "curve into" the actual "here and now" and confer its dynamics of admonition and comfort. In our pericope, the addressees have not yet reached their "homeland." The voyage to this eschatological "homeland" is dangerous, as the past will instruct; however, it is possible to reach as the future has promised.

By the way, we hardly know anything about the author of the Epistle to the Hebrews, nor about his addressees. I surmise that he had lived in Rome and that he wrote to his fellow believers in Rome. Although, at the time he wrote his letter, he no longer lived in Rome. ${ }^{4}$ While we do not know the real author, we do know the voice of the implicit author of Hebrews. ${ }^{5}$ He presents himself as a teacher and preacher who directly addresses and admonishes his listeners. In this respect, the implicit author is even more vigorous than the real author; his strength is his anonymity. The narrative addressees and the implicit addressees are probably the same, as the author speaks to them in the second person plural continuously. ${ }^{6}$ The aim of his letter was probably to admonish those Christians who had come from Judaism but were on the verge of relapsing into Judaism: "recidivists," so to speak, that he wanted to move back again towards Christianity. |

Let us return to our pericope. Hebrews 3:7-4:11 is a kind of Christian homiletic midrash ${ }^{7}$ of Ps 95:7b-11 in the Septuagint version (Ps 94:7b-11 LXX) which the author connects with Gen $2: 2 .{ }^{8}$ It can be divided into three parts:

(1) introduction of the Old Testament text: 3:7-11;

(2) interpretation: 3:12-19;

(3) consequence: $4: 1-11 .^{9}$

${ }^{4}$ Cf. Heb 13:24 and 2:16.

${ }^{5}$ Whether something like an implicit author exists is a matter of debate. An implicit author is a kind of text-immanent second self of the real author. Although the concept of such a "second self" is hardly manifest, in the exegesis of the Letter to the Hebrews it works very well.

${ }^{6}$ See in Hebrews the many occurrences of the verbs $\dot{\alpha} \kappa o v ́ \omega$ and $\lambda \dot{\varepsilon} \gamma \omega$ with their derivates and

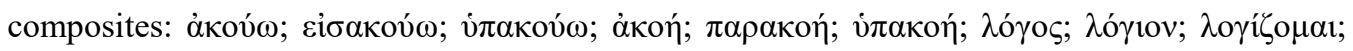

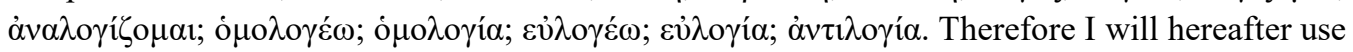
the term "addressees" indiscriminately. |

${ }^{7}$ Kraus 2008. For an overview of questions concerning midrash, see Neusner and Avery-Peck 2004. Enns $(1997,352)$ labels the text a pesher. However, in a pesher each element of a text gets one specific meaning in a linear way. The exegesis of Heb 3:7-4:11 is clearly different.

${ }^{8}$ And he alludes to Deut 12:9 as well as to Num 14, 20:1-13, and Exod 17:1-7. See Hossfeld and Zenger 1999, 664-65.

${ }^{9}$ And (4) "The power of the word of God": 4:12-13. However, it is highly debated whether vv. 12-13 belong to the pericope. Most exegetes consider 3:7-4:11 to be a pericope; a few, such as, for example, Vanhoye (1989) and Gräßer (1990), extend it to v. 13. 
The author cites Ps 94 LXX almost verbatim, ${ }^{10}$ from v. 7 up to v. 11, in which God swears to the Israelite people in the wilderness: "They shall not enter my rest" (Ps 95 [94]:11 = Heb 3:11) - a proposition with spatial and time aspects. This rather uncomforting sentence seems to be important for the author since he repeats it three times within Heb 3:7-4:11 $(3: 11 ; 4: 3,5)$, and also refers to it at one time (3:18). ${ }^{11}$ The addressees will not have missed this. ${ }^{12}$

From the sentence, "They shall not enter my rest," the author picks out the

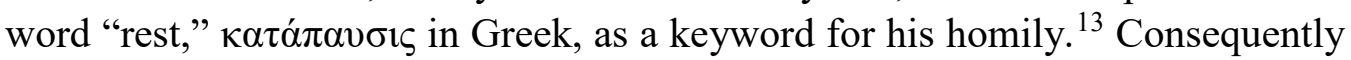

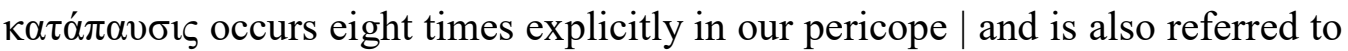
three times implicitly. ${ }^{14}$ In addition, the verb $\kappa \alpha \tau \alpha \pi \alpha v$ w, "to rest," occurs thrice. ${ }^{15}$ In comparison to the rest of the New Testament, this is a respectable number,

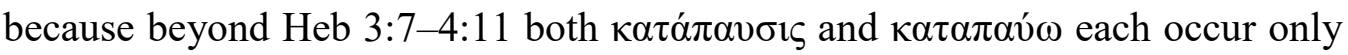

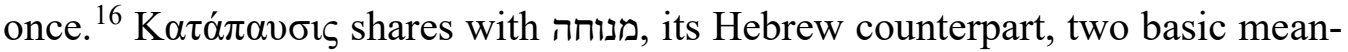
ings: first, rest as resting place; and, second, rest as a state of physical/psycho-

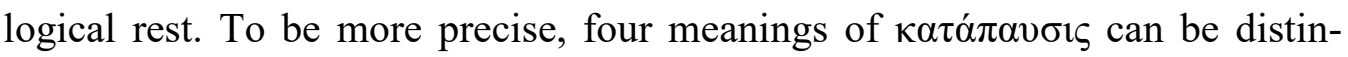
guished in the Greek Bible: 17 "rest" as:

10 Most differences between the two texts are of minor importance: Ps 94:7b-11 lxx :: Heb

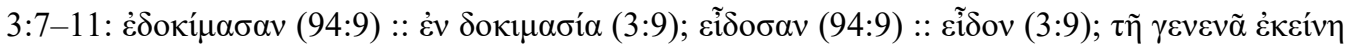

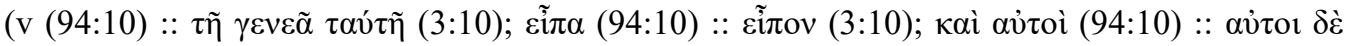

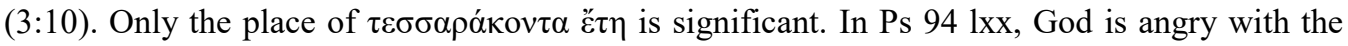
wilderness generation for forty years (94:10); in Hebrews the forefathers have seen the works of God for forty years (3:9-10). The author connects this by the addition of the conjunction $\delta$ io with the statement about the anger of God (3:10). So the meaning of Heb 3:9b becomes concessive.

11 Erich Gräßer designates Ps 95, and even more the Septuagint version of it a "Paradigma des Unglaubens" (Gräßer 1990, 179).

12 This is stressed by DeSilva (2000).

13 A large number of studies have been published about the theme of "rest" in the New Testament and in Gnosis. To mention some examples: von Ras 1958; Hofius | 1970; Helderman 1984; Laansma 1997; Wray 1998; Gleason 2000; Bénétreau 2003.

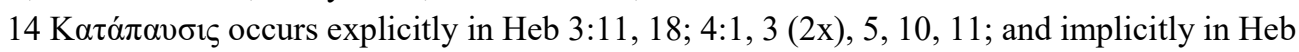
3:19; 4:6 (2x).

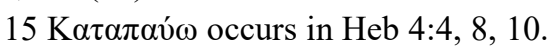

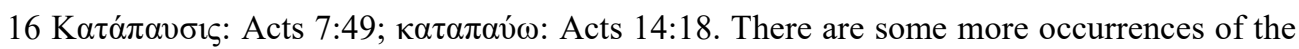

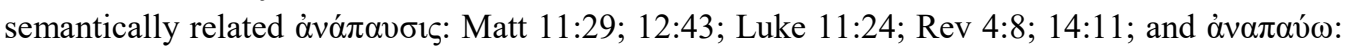
Matt 11:28; 26:45; Mark 6:31; 14:41; Luke 12:19; 1 Cor 16:18; 2 Cor 7:13; Phlm 1:7, 20; 1 Pet $4: 14 ; \operatorname{Rev} 6: 11 ; 14: 13$.

17 Kató $\pi \alpha v \sigma 1 \zeta$ occurs, surprisingly, only thirteen times in the Septuagint: Exod 35:2; Num 10:35; Deut 12:9; Judg lxx-a 20:43; 3 Kgdms 8:56; 1 Chr 6:16; 2 Chr 6:41; Jdt 9:8; 2 Macc 15:1; Pss 94:11 lxx; 131:14 lxx; Sir 5:6; Isa 66:1. 
(1) a state of resting; ${ }^{18}$

(2) a synonym for Sabbath; ${ }^{19}$

(3) a resting place or inheritance of the Israelite people, ${ }^{20}$

(4) the location where God or the ark settles down or dwells. ${ }^{21}$

The first two meanings denote states of resting; the second two denote locations

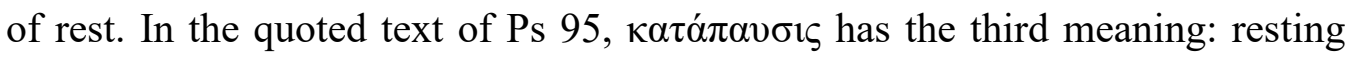
place or inheritance of the people; in other words: the Promised Land of Canaan. The fourth meaning, however, "resting place or dwelling place of God or the ark," is typical in the Septuagint with six out of a total of 13 matches. Did the author of our pericope know all these meanings? Yes he did. More than that, he plays with the polysemes of the word, and eventually, combines all four meanings. I shall try to illustrate | that by a sort of homiletical exegesis, fitting the character of the text and focusing on images of space and time and their pragmatic functions.

\section{Exegesis}

3:7a: In Ps 94 LXX (= Ps 95 MT), the quoted text, it is God who speaks; in Heb 3 it is the Holy Spirit who speaks. This connects the situation of Ps 95 directly with the contemporary presence of the hearers of Hebrews. The same God, who once spoke to the Israelites as they were going astray in the desert, is speaking now by his Holy Spirit. Please notice also the praesens $\lambda \varepsilon \dot{\gamma \varepsilon l .}{ }^{22}$ The author of Hebrews builds an imaginative bridge between present and past. He takes his audience thereby back to the desert and rebukes them by means of the words of the Holy Spirit, as God had once rebuked the Israelites.

$\Delta$ ó, the first word of the pericope, connects the quotation with the foregoing statement of Heb 3:6b " (...) we [the Christians] are his [Christ's] house if we hold firm the confidence and the pride that belong to hope." ${ }^{23}$ The statement is both consoling and threatening: consoling, in so far as Christians belong, as a kind of family, to the house of Christ; threatening, by the condition "if we hold firm the confidence and the pride that belong to hope." As Heb 3:7 proceeds with a rebuke, the line of argument is in the first instance that of the danger of losing "the

${ }^{18}$ Judg 20:23 LXX-A; 3 Kgdms 8:56.

${ }^{19}$ Exod 35:2; 2 Macc 15:1.

${ }^{20}$ Deut 12:9; Ps 94:11 LXX.

${ }^{21}$ Num 10:34; 1 Chr 6:16; 2 Chr 6:41; Jdt 9:8; Ps 132 [131]:14; Isa 66:1 (there as a negation of God's dwelling on earth). Jdt 9:8, where the Temple is designated as $\tau$ ò $\sigma \kappa \eta ́ v \omega \mu \alpha ~ \tau \tilde{\eta} \varsigma$

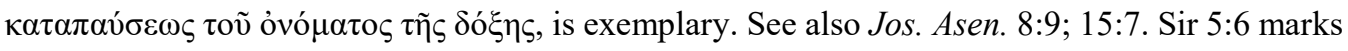
an exception. There, rest is connected with the anger of God that rests on sinners. |

22 See Löhr 1994a, 229-31.

${ }^{23}$ Biblical quotations are from the NRSV. 
house of Christ." The syntactical connection of $\delta$ io to the following text is less clear. There are three possible explanations: ${ }^{24}$

(1) There is no connection to the following;

(2) Sió connects to v. 8: "(Therefore...) do not harden your hearts";

(3) it connects to v. 12: "(Therefore...) take care, brothers and sisters, that none of you may have an evil, unbelieving heart that turns away from the living God."

The whole line of thought in the pericope speaks in favor of the third explanation. The lengthy quotation of Ps 95:7b-11, thus, prepares the admonition of v. 12 in a negative exemplary way.

3:7b: The audience will relate the quotation of Ps 95 to themselves. The $\sigma \eta \dot{\mu} \varepsilon \rho \circ \mathrm{v}$, the "today" of the quotation and the direct speech in the second | person plural, "Today, if you hear his voice," are conductive to this transmission up to the time of the hearers, up to their "here and now." Topologically there is an outside-inside relation: the voice of the Holy Spirit comes from outside (and from above) and pervades the audience. Illocutivily, a hierarchical relation emerges; perlocutively, the advertence of the hearers is pressed.

3:8 warns or blames the addressees for making their hearts hard. Up to the end of $3: 8 \mathrm{a}$, all the words so far can apply directly to the contemporary addressees of the Epistle to the Hebrews. The phrase "as in the rebellion" could, if technically read, already hint at the rebellion of the Israelites in the desert; but it is only at the end of 3:8 that the wilderness comes explicitly to the fore, and with that a period which lies before (or behind) the implicit addressees. This is marked by

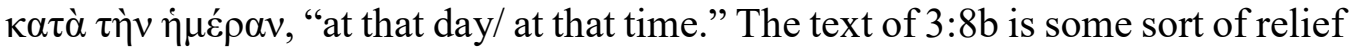
for the addressees because the rebellion took place in a past time. The time perspective is now - once. Since the Holy Spirit is still speaking the connecting topological perspective for both times is outside-inside. A so-called memory space emerges. The hearers are in the desert together with their ancestors in a mental way.

$3: 9 a$ relocates, again the time of the rebellion, to the time of the ancestors. This is soothing. But at the same time the phrase oi $\pi \alpha \tau \varepsilon \dot{\varepsilon} \rho \varsigma \zeta \mu \tilde{v} v$, "your ancestors," links the rebellion to the present generation.

$3: 9 b-11$ plays in the past. It applies to $\tau \tilde{\eta} \gamma \varepsilon v \varepsilon \tilde{\alpha}$, "that generation" (3:10a). This

${ }^{24}$ Löhr 1994b, 89. 
generation was so stubborn that God swore to them that they would not enter his

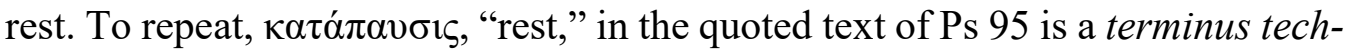
nicus for the Promised Land, the Land of Canaan: the land where the Israelites will come to rest. A future in the past which had been lost: the promised, but forfeited, entrance into the Land of Canaan. I do not know whether the hearers of our text still remember that the quotation was introduced by dió, although they will have understood the threatening undertone: "If you are as stiff-necked as

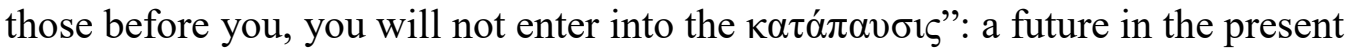
which is at stake.

In 3:12 it becomes obvious that the author targets his hearers when he quotes Ps 95. He warns his hearers against lack of faith, which consists of $\dot{\alpha} \pi 0 \sigma \tau \tilde{\eta} v \alpha$, being distant from God. We have a new perspective here, that is, God is distant in place, he is above; and in time, he is in the future. The temptation of once $(3: 8 \mathrm{~b})$ be-

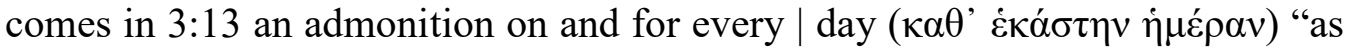
long as it is called 'today' ( $\sigma \eta \dot{\mu \varepsilon \rho o v) . " ~ T h e ~ a u t h o r ~ p l a y s ~ w i t h ~} \sigma \eta \dot{\mu \varepsilon \rho o v, ~ " t o d a y " ; ~}$ it is the "today" of the past, an abhorring example; it is the "today" of the wandering, on the way to overcome distance; and it is the "today" of the promised future of being at home and of nearness. In short, at the end, it is a soteriological "today." 25

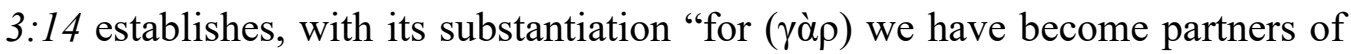

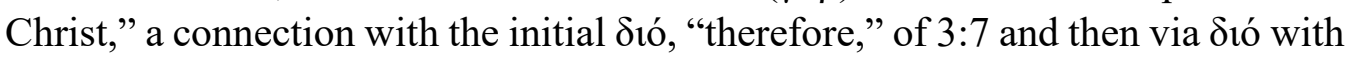
the foregoing pericope $3: 1-6$. Just as in 3:6, where being a house of Christ was bound to confidence, here being partners of Christ is bound to confidence to the end: a condition, which is connected with a statement in the perfect, $\gamma \varepsilon \gamma o$ ov $\alpha \varepsilon v$. They have already become partners of Christ, but only if they remain confident on their way until the end.

In 3:15 the first part of the initial quotation is repeated. But now it is clear that

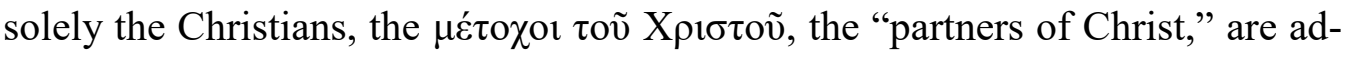
dressed, not the generation which was once in the wilderness. $\Sigma \eta \mu \varepsilon \rho o v$ is now the "today" of the addressees.

3:16-17 focuses back on the wilderness generation. All of those who were rebellious and had sinned had died in the wilderness.

25 Cf. for this aspect of "today" Bäumer 2003, 699. In Hebrews we find the first "today" in $1: 5 ;$ cf. $1: 2$. 
This leads the author to the maxim in 3:18-19 that God lets nobody enter his rest who is disobedient, who does not believe. This is a message that applies equally to the wilderness generation and to the contemporary audience.

In $4: 1$ there is hope. The promise ( $\left.\dot{\varepsilon} \pi \alpha \gamma \gamma \varepsilon \lambda i^{\prime} \alpha\right)$ to come into God's rest is still

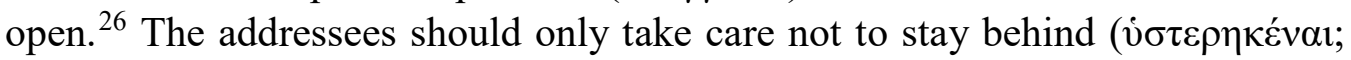

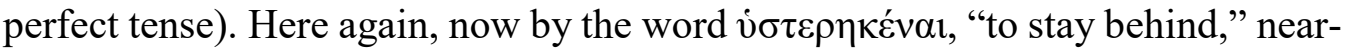
ness, distance, and movement, a being on the way, are implied. This observation is not new. Ernst Käsemann had labelled the Christians of Hebrews a "wandering

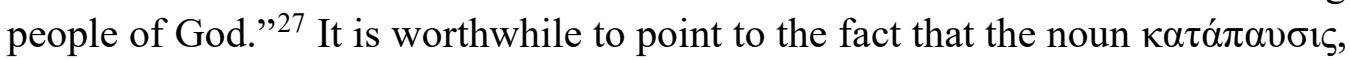

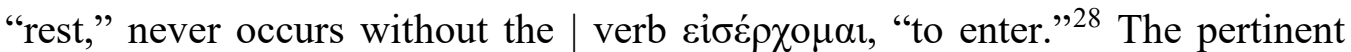
question here is: To enter into what? Are the addressees just as the wilderness generation on their way to the Promised Land? Yes, they are on their way to the Promised Land but not to the Land of Canaan/Israel.

In 4:2-3a faith is connected with having heard the good news, $\dot{\varepsilon} \sigma \mu \varepsilon v$

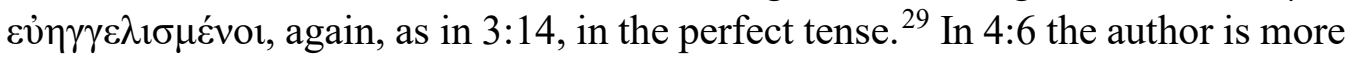
explicit; there he speaks about those "who formerly ( $\tau$ ò $\pi \rho$ ó $\tau \varepsilon \rho o v$ ) received the good news." We can presume that here the author means Christians from Jewish origin, but who, by returning to Judaism, did not adhere to confidence, to faith.

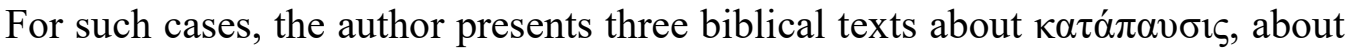
rest: the multiply quoted Ps $95(4: 3,5)$; the account of God resting after creation $(4: 3,4)$; and the success 1 conquest of Canaan by Joshua which, however, had not given the Israelites rest $(4: 8) .{ }^{30}$

We can read about the creation (4:3-4) that all God's works are established before God rested on the seventh day. That means that, among others the

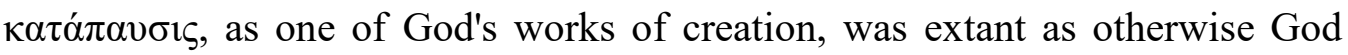
could not have rested. ${ }^{31}$ The " $\rho \gamma \alpha$, the works of God, occurred already in 3:9-10, with respect to the works that the wilderness generation had seen but which had not led them to obedience. The two occurrences of " $\rho \gamma \alpha$ in 3:9 and in 4:4 connect, by keyword connection, the history of the Israelites with the creation of the world. And in 4:10 the है $\rho \gamma \alpha$ pop up in relation with those who will enter God's rest in

26 For the meaning and function of $\dot{\varepsilon} \pi \alpha \gamma \gamma \varepsilon \lambda i \alpha$, an important theologoumenon in Hebrews, see Rose 1989.

27 Käsemann 1957; English: Käsemann 1984.

28 Hebrews $3: 11,18 ; 4: 1,3,5,10-11$; implicitly in 4:6. See also other words in the pericope

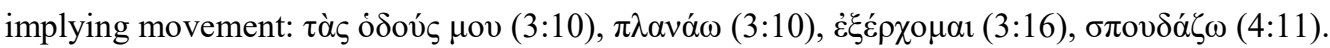

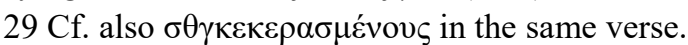

30 On the relationship between Joshua and Jesus, see Whitfield 2010, de Vos 2012a, and Ounsworth 2012.

31 See, for space concepts in Antiquity, Zekl 1992; Algra 1995; Heuner 2006. 
the future.

A similar keyword connection can be found in the occurrences of $\dot{\eta} \mu \varepsilon \dot{\rho} \rho$, "day": $3: 8$ - the day of testing in the wilderness; $3: 13$ - every day of the addressees; 4:4 - the seventh day of creation; 4:7 - a new day as today; 4:8 - a later day in the future. We can once more notice a connection of creation, past, today, and future.

Rest is as a work of creation principally extant, but the Israelites have, nevertheless, not yet come to rest. The proof for the author of Hebrews is that if Joshua had given real rest to the Israelites, God would not speak later, that is, in Ps 95 by David, about another day (4:7-8). But the $\sigma \eta \mu \varepsilon \rho o v$, the "today" of Ps 95, is still valid both now and in the future. | The keyword connection between rest after creation and rest in Ps 95 leads to a melting of the significances of the two kinds

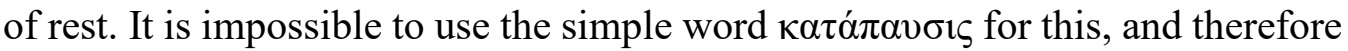
the author of Hebrews creates a new word, $\sigma \alpha \beta \beta \alpha \tau 1 \sigma \mu{ }^{\prime} \varsigma_{;}^{32}$ a word with the connotations that it is:

(1) a constitutive work of God;

(2) that God rested - rest is here a state of resting;

(3) that it is some sort of place, similar to the resting place of Ps 95, that is, the Promised Land.

In Antiquity combining texts and their content by matching keywords was a valid hermeneutical rule. ${ }^{33}$

Only after this merging of meanings, does v. 11 acquire its meaning: "For those who enter God's rest also cease from their labors as God did from his." In other words, entering the rest means just like God entering into a realm of rest, entering

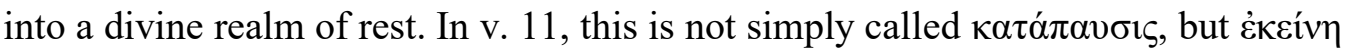
$\dot{\eta} \kappa \alpha \tau \dot{\alpha} \pi \alpha v \sigma \mathrm{\varsigma}$, , "that (sc. qualified) rest," a rest with all the above-mentioned connotations. Time, creation, past, present, and future as well as space, creation space, wilderness, the Promised Land, the dwelling place of the addressees, and the divine realm are connected with each other and even mingle. That which cannot simultaneously be formed in technical space, can be expressed by words and can be properly imagined and understood.

\section{Striving to Be at Home}

In order to understand what is expressed by means of words, these words are to be translated into a mental time-space landscape. The mind brings together what

\footnotetext{
32 See the excursus in Gräßer 1990, 218-20.

${ }^{33}$ In the later rabbinical hermeneutics, this was called "gezera shawa”. See Gräßer 1990, 20911 and Bénétreau 2003. Regarding the term "gezera shawa” itself see Stemberger 1992, 28-29, and in particular Basta 2006.
} 
written and heard texts cannot achieve on their own. The mind goes beyond borders of actual time and space. Memory spaces become actual spaces as well as future spaces and vice versa. ${ }^{34}$ With respect to the Epistle to the Hebrews: a "today" from the past situated in the wilderness is a "today" in the contemporaly "wilderness" of the addressees of Hebrews; and it is a "today" of the future, because the "Hebrews§ are going astray and have not yet reached their destination. | The wilderness is the wilderness of once before, it is the "dry spell" of now and it can be the "runway" to the promised space of divine proximity. Only on one occasion, in Heb 7:19, is this divine proximity stated explicitly; it says: "there is, on the other hand, the introduction of a better hope, through which we approach God." The author of Hebrews admonishes his hearers in many places to stay on the right path. To where does this path lead? It leads to the divine realm, considered to be spatial. The people of Hebrews are on their way to God himself - he is their "homeland" in some way. ${ }^{35}$

The "homeland" has a couple of imageries in Hebrews of which I would like to highlight that of the "house" and that of the "city." I have already touched a few times on the subject of "the house." The house is the space par excellence which belongs to the private sphere of an individual or group. The inhabitants of a house belong together by real or fictive family bonds. It is no coincidence that the metaphor of the "house" (oĩ Testament. Just before our pericope, in Heb 3:6, the addressees of the Epistle to the Hebrews are referred to as "house of Christ." Just as in 3:7-4:11, in 3:6 the space of this "house" is not given, but is conditioned: "We are his house if we hold firm the confidence and the pride that belong to hope" (3:6; cf.3:14). Only if the conditions are fulfilled does a "house" emerge, which symbolizes the familiar nearness to Christ. This space does not exist per se, it is constructed.

Emmanuel Lévinas has worked out in his Totalité et infini (1961) that the house, le demeure, l'habitation, as symbol of "the own" does not only guarantee a feeling of security, but also figures the world:

Concretely speaking, the dwelling is not situated in the objective world, but the objective world is situated by relation to my dwelling. The idealist subject which constitutes a priori its object and even the site at which it is found does not strictly speaking constitute them a priori but precisely after the event, after having dwelt in them as a concrete being. The event of dwelling exceeds the $\mid$ knowing, the thought, and the idea in which, after the event, the subject

34 See the contribution of Bieberstein in this volume.

35 Many other texts in Hebrews can substantiate this. Compare the occurrences of

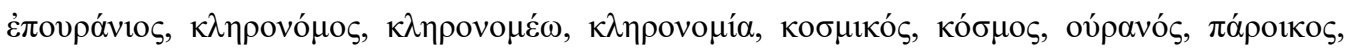

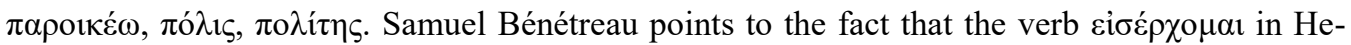
brews goes, with two exceptions, always together with a coming into the realm of God (2003, 213). Exceptions are to be found in 10:1 and 12:18.

36 In Hebrews of the three words oî́אo occurs: 3:2, 3, 4, 5, 6 (2x); 8:8, 10, 21; 11:7. | 
will want to contain what is incommensurable with a knowing. ${ }^{37}$

Lévinas concentrates on the individual. However, what applies for the individual also applies, mutatis mutandis, for the group, and in this case for the family. To expand on this, a house and a family belong more closely together than a house and an individual. The individual can be connected to $\tau \hat{\alpha}$ ' $\delta \delta 1 \alpha$, "the own," at the most; the house is more comprehensive. ${ }^{38}$

This constructed house leads to a feeling of security, a feeling of being at home, a feeling of intimacy. Those who live within one house are mostly akin, and if they are not directly akin, they are close to each other. Those who live in one house belong to a family in the broad sense of the word.

It is asserted by many sociological and socio-psychological studies that space creates shared identity, and this identity in tu creates shared space. This shared space does not have to be real, it can also be mental. However, when a socioreligious group positions itself in a space which is not concrete, the same group can orient itself better within the real space. In this manner, a Christian group can be at home within a non-Christian society. Identity emerges both by separation and acculturation: Divine space as orientation binds the people of Hebrews together.

The Christians have de ned themselves from the beginning as a mily with God as ther and Christ as brother. We can nd examples of this perspective in the Epistle to the Hebrews as well. I would like to point to two occurrences:

2:11: For the one who sanctifies and those who are sanctified all have onFather. For this reason Jesus is not ashamed to call them brothers and sisters...

2:13: And again, "I will put my trust in him." And again, "Here am I and the children whom God has given me."।

The early Christians needed a "house" for their "family." Since they did not really have such a center, they constructed a "house" with God as the father of the "house." But because one cannot have God at one's disposal, the utterances about God's dwelling in the house are all conditional. So the conditional statements are in fact declarations of faith and hope that God will in future dwell together with

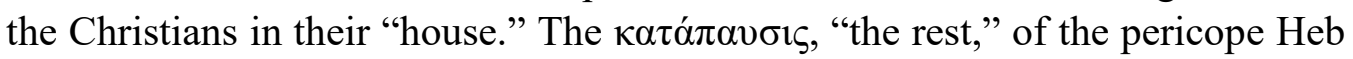

37 Lévinas 1991, 153. Translation of the original French: " Concrètement, la demeure ne situe pas dans la monde objectif, mais le monde objectif se situe par rapport à ma demeure. Le sujet idéaliste qui constitue a priori son objet et même le lieu où il se trouve, ne les constitue pas, à parler rigoureusement, a priori, mais précisément après coup, après avoir demeuré, comme être concret, en lui, débordant le savoir; la pensée et l'idée où le sujet voudra, après coup, enfermer l'événement de demeurer qui est sans commune mesure avec un savoir » (Levinas 1961, 126).

38 Cf. the well-known phrase from John 14:2: "In my Father's house there are many $\mu$ ovaí." For the topological image of John 14 see de Vos 2012b, 175-82. | 
3:7-4:11 is, to my opinion, a kind of heavenly house.

On the other hand, we have the imagery of the heavenly city. The well-known passage from Heb 13:14, "For here we have no lasting city, but we are looking for the city that is to come," tells that the perspective of the early Christians addressed to in Hebrews is a future city. Many verses in Heb 11 and 12:28-29 let us assume that the future city is the city of God. Abraham, in ch. 11, "looked forward to the city that has foundations, whose architect and builder is God" (Heb 11:10). And the following quotation from Heb 11:13-16 may substantiate my assumption:

They confessed that they were strangers and foreigners on the earth, for people who speak in this way make it clear that they are seeking a homeland $(\pi \alpha \tau \rho i \delta \alpha)$. If they had been thinking of the land that they had left behind, they would have had opportunity to return. But as it is,

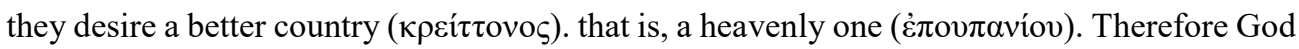
is not ashamed to be called their God; indeed, he has prepared a city ( $\pi$ ó $\lambda \imath v$ ) for them. ${ }^{39}$

In Heb 12:22, the Mountain of Zion is equated with the city of the living God and the heavenly Jerusalem, thus becoming some sort of "runway" for its own transcendence of being the heavenly Zion.

The imageries of the house, the homeland, and the city all share the familiarity of the "partners of Christ" (3:6) with each other and with God and the proximity to God. That is why they can mingle under the heading of "being at home" or, better, "being at the real home."

\section{Conclusions}

In Heb 3:7-4:11 the Old Testament topic of the "rest," there connected with the Promised Land, is taken up, but it is modified into a rest that has, first, a cosmological foundation in creation, because it was one of the works of God, and that has, second, a theological foundation in God himself, since God rested on the seventh day after the completion of the $\mid$ creation. So if the people of Hebrews are on their way to "this rest" ( on their way to God/his realm. That is their real, albeit eschatological home. ${ }^{40}$ Neveltheless the way and the destination are clear.

"Rest" in Heb $3: 7-4: 11$ is the keyword that binds together past, present, and future. It creates a cosmological, divine, and eschatological space that marks the orientation of the addressees of Hebrews. It admonishes and it comforts them. It

39 A convincing study on the "real homeland" of the addressees of Hebrews, especially in Heb 11, is Backhaus 2001. |

40 See also Enns 1997. I do not understand why Judith Hoch Wray concludes "that REST remains an undeveloped and unsustained theological metaphor in the Epistle to the Hebrews because ENTERING INTO THE REST has not become a part of the Christology of the writer of Hebrews" (Wray 1998, 91). ls that necessary? | 
gives them a position, a feeling of security in their socio-religious "today." In short, it gives them rest and a resting place: at once actual, transitional, and eschatological.

\section{Works Cited}

Algra, K. A. 1995. Concepts of Space in Greek Thought. Philosophia antiqua 65. Leiden: Brill.

Backhaus, K. 2001. Das Land der Verheißung: Die Heimat der Glaubenden im Hebräerbrief. NTS 47: $171-88$.

Basta, P. 2006. Gezerah shawah: Storia, forme e metodi dell' analogia biblica. Subsidia Biblica 26. Rome: Pontificio Istituto biblico.

Baudy, G. 1998. Orientierung. In Cancik et al. 1998, 4:293-30I.

Bäumer, B. 2003. Sakraler Raum und heilige Zeit. Pages 690-701 in Handbuch Religionswissenschaft. Religionen und ihre zentralen Themen. Edited by J.Figl. Innsbruck: Tyrolia-Verlag/Vandenhoeck \& Ruprecht.

Bénétreau, S. 2003. Le repos du pelerin (Hebreux 3,7-4,11). Études théologiques et religieuses 78: 203-23.

Cancik, H. et al., eds. 1998. Handbuch religionswissenschaftlicher Grundbegriffe. 5 vols. Stuttgart: Kohlhammer.

DeSilva, D. A. 2000. Entering God's Rest: Eschatology and the Socio-RhetoricaJ Strategy of Hebrews. Trinity Journal 21:25-43.

Enns, 1997. The Interpretation of Psalm 95 in Hebrews 3:1 :13. Pages 352-63 in Early Christian Interpretation of the Scritures of Israel: Investigations and Proposals. Edited by C. A. Evans and J. A. Sanders. JSNTSup 148. Sheffield: Sheffield Academic.

Gehlen, R. 1995. Welt und Ordnung: Zur soziokulturellen Dimension von Raum in frühen Gesellschaften. Religionswissenschaftliche Reihe 8. Marburg: Diagonal-Verlag.

----. 1998. Raum. In Cancik et al. 1998, 4:377-98.

Gleason, R. C. 2000. The Old Testament Background of Rest in Hebrews 3:7-4:11. Bibliotheca sacra 157: 281-303.

Gräßer, E. 1990. An die Hebräer (Hebr 1-6). Evangelisch-katholischer Kommentar zum Neuen Testament 17/1. Zürich: Benziger/Neukirchener.

Helderman, J. 1984. Die Anapausis im Evangelium Veritatis: Eine vergleichende Untersuchung des valentinianisch-gnostischen Heilsgutes der Ruhe im Evangelium Veritatis und in anderen Schrifen der Nag Hammadi-Bibliothek. Nag Hammadi Studies 18. Leiden: Brill.

Heuner, U., ed. 2006. Klassische Texte zum Raum. Berlin: Parodos.

Hofius, 0. 1970. Katapausis: Die Vorstellung vom endzeitlichen Ruheort im Hebräerbrief WUNT II. Tübingen: Mohr Siebeck.

Hossfeld, F.-L., and E. Zenger. 1999. Psalmen 51-100, Herders theologischer Kommentar zum Alten Testament. Freiburg: Herder.

Käsemann, E. 1957. Das wandernde Gottesvolk: Eine Untersuchung zum Hebräerbrief 2d ed. FRLANT 55. Göttingen: Vandenhoeck \& Ruprecht.

---. 1984. The Wandering People of God: An Investigation of the Letter to the Hebrews. Translated by R. A. Harrisville and I. L. Sandberg. Minneapolis: Augsburg.

Kraus, W. 2008. Hebrews 3:7-4:11 as a Midrash on Psalm 94 LXX. Pages 275-90 in Florilegium Lovaniense: Studies in Septuagint and Textual Criticism in Honour of Florentino Garcia Martinez. Edited by H. Ausloos et al. Ephemerides theologicae lovanienses 224. Leuven: Peeters. 
Laansma, J. 1997. "I will give you rest": The "Rest" Motif in the New Testament with Special Reference to Mt 11 and Heb 3-4. WUNT 2/98. Tübingen: Mohr Siebeck.

Levinas, E. 1961. Totalité et infini: Essai sur l' extériorité. The Haag: Nijhoff.

---. 1991. Totality and Infinity: An Essay on Exteriority. Translated by A. Lingis. 3d ed. Kluwer: Dordrecht.

Löhr, H. 1994a. "Heute, wenn ihr seine Stimme hört.“ Zur Kunst der Schriftanwendung im Hebräerbrief und in 1 Kor 10. Pages 226-48 in Schriftauslegung im antiken Judentum und im Urchristentum. Edited by M. Hengel and H. Löhr. WUNT 73. Tübingen: Mohr Siebeck.

---. 1994b. Umkehr und Sünde im Hebräerbrief BZNW 73. Berlin: de Gruyter.

Neusner, J., and A. J. Avery-Peck, eds. 2004. Encyclopedia of Midrash: Biblical Interpretation in Formative Judaism. Leiden: Brill.

Ounsworth, R. 2012. Joshua Typology in the New Testament. WUNT 2/328. Tübingen: Mohr.

Pezzoli-Olgiati, D. 2003. Orientation. Pages 655-56 in vol. 6 of Religion in Geschichte und Gegenwart. Edited by H. D. Betz et al. 4th ed. Tübingen: Mohr.

Rad, G. von. 1958. Es ist noch eine Ruhe vorhanden dem Volke Gottes: Eine biblische Begriffsuntersuchung. Pages 101-108 in vol. 8 of Gesammelte Studien zum Alten Testament. Edited by G. von Rad. Munich: Kaiser.

Rose, C. 1989. Verheißung und Erfüllung: Zu Verständnis von غ̇ $\alpha$ $\gamma \gamma \varepsilon \lambda \lambda^{i ́ \alpha}$ im Hebräerbrief. Biblische Zeitschrift 33: 60-80, 178-91.

Stemberger, G. 1992. Einleitung in Talmud und Midrasch. 8th ed. Munich: Beck. Vanhoye, A. 1989. Structure and Message of the Epistle to the Hebrews. Subsidia biblica 12. Rome: Pontificio Istituto biblico.

Vos, J.C. de. 2012a. Josua und Jesus im Neuen Testament. Pages 524-40 in The Book of Joshua. Edited by E. Noort. Bibliotheca ephemeridum theologicarum Lovaniensium 250. Leuven: Peeters.

---. 2012b. Heiliges Land und Nähe Gottes. Wandlungen alttestamentlicher Landvorstellungen in frühjüdischen und neutestamentlichen Schriften. FRLANT 244. Göttingen: Vandenhoeck \& Ruprecht. |

Whitfield, B. J. 20 I 0. The Three Joshuas of Hebrews 3 and 4. Perspectives in Religious Studies 37: $21-35$.

Wray, J. H. 1998. Rest as a Theological Metaphor in the Epistle to the Hebrews and the Gospel of Truth: Early Christian Homiletics of Rest. SBLDS 166. Atlanta: Scholars Press.

Zekl, H. G. 1992. Raum. I: Griechische Antike. Pages 67-82 in vol. 8 of Historisches Wörterbuch der Philosophie. Edited by J. Ritter et al. 13 vols. Basel: Schwabe, 1971-2007. 